\title{
Optical coherence tomography classification of indirect choroidal ruptures: conclusive or misleading?
}

This article was published in the following Dove Press journal:

Clinical Ophthalmology

18 March 2015

Number of times this article has been viewed

\section{Vishaal Bhambhwani Shagun Sood}

Guru Nanak Eye Centre and Maulana Azad Medical College, New Delhi, India
Correspondence: Vishaal Bhambhwan Guru Nanak Eye Centre, Ranjit Singh Marg, New Delhi I I0002, India Tel +9l 97 I | 456784

Email vishaalb@ymail.com

\section{Dear editor}

We read with interest the article by Nair et al. ${ }^{1}$ We would like to make the following observations by analyzing a case of indirect choroidal rupture (ICR) which presented at our center, and which may question the authors' theories.

The authors state that there are two types of ruptures distinguishable on optical coherence tomography (OCT). The first type seen (type 1 ICR) was a forward protrusion of the retinal pigment epithelium-choriocapillaris (RPE-CC) layer with an acutely angled pyramid or dome shape. This was associated with either a small loss of continuity of the retinal pigment epithelium layer or elevated RPE-CC projection accompanied by a significant quantity of subretinal hemorrhage. The second type observed (type 2 ICR) was a larger area of disruption of the RPE-CC layer, photoreceptor inner segment/ outer segment junction, and external limiting membrane, with a posteriorly directed concave contour depression at that area and downward sliding of tissues into the defect. There was no scenario in which the two types of ICR coexisted, either in the same rupture or in the same eye. Further, the authors hypothesize different mechanisms of

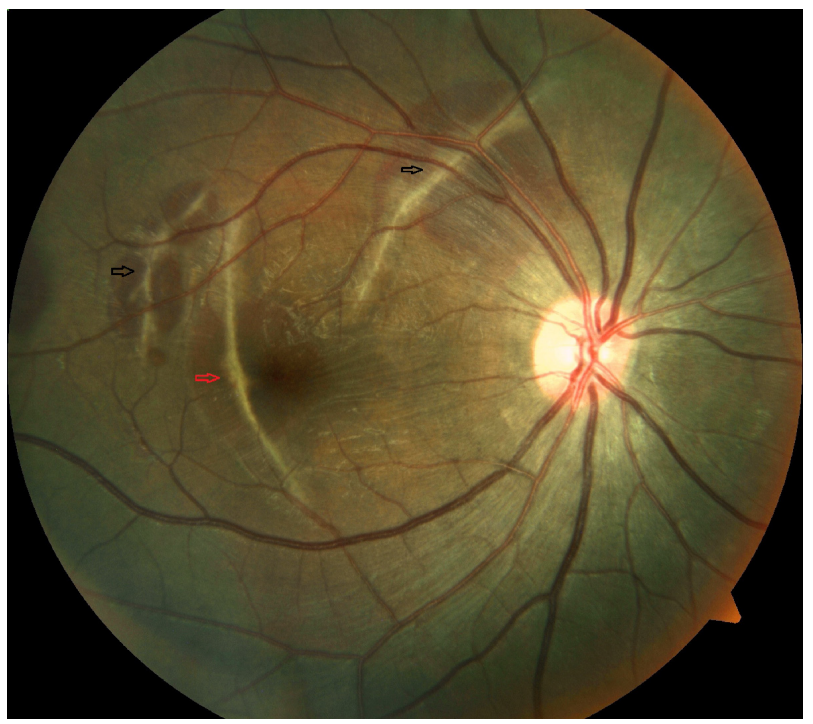

Figure I Fundus photo right eye showing multiple indirect choroidal ruptures with sub-retinal blood (black and red arrows).

Note: One of the ruptures is involving the fovea (red arrow). 

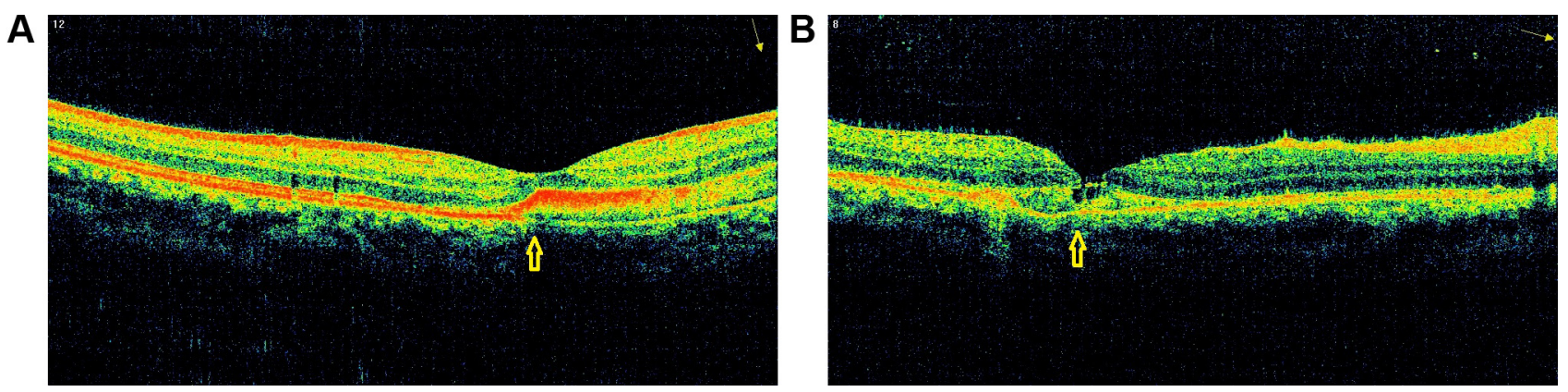

Figure 2 Optical coherence tomography (OCT) of choroidal rupture involving fovea.

Notes: (A) OCT of choroidal rupture involving fovea showing features of type I ICR (yellow arrow). (B) OCT of choroidal rupture involving fovea showing features of type 2 ICR (yellow arrow).

Abbreviation: ICR, indirect choroidal rupture.

injury for these two types and also state differences in the incidence of complications like the development of choroidal neovascularization.

We believe that this differentiation, on the basis of OCT findings alone, is artificial. Both types ( 1 and 2 ) may be seen in the same rupture as exemplified by the following case which presented at our center.

A 20-year-old male, with a history of road traffic accident with blunt trauma to right side of forehead due to fall from a motor vehicle, presented at our center with best corrected visual acuity of finger counting at $4 \mathrm{~m}$ right eye and 20/20 left eye. There was bulbar conjunctival congestion with a subconjunctival hemorrhage OD. The rest of the anterior segment was unremarkable. Fundus evaluation OD showed multiple ICRs with sub-retinal blood. One of the ruptures was involving the fovea (Figure 1). Fundus OS was unremarkable.
OCT findings of the ICR involving the fovea, we believe, demonstrate features of both type 1 (Figure 2A) and type 2 (Figure $2 \mathrm{~B}$ ) choroidal rupture. In one section there is an elevated RPE-CC projection with small loss of RPE continuity with subretinal hemorrhage. In the other section there is extensive disruption of the RPE-CC layer with photoreceptor layer abnormalities. Thus features of both types, we believe, may be seen in a single rupture.

Thus, in our opinion, the classification of ICRs on the basis of OCT findings alone may be artificial and inconclusive.

\section{Disclosure}

The authors have no conflicts of interest to report.

\section{Reference}

1. Nair U, Soman M, Ganekal S, Batmanabane V, Nair K. Morphological patterns of indirect choroidal rupture on spectral domain optical coherence tomography. Clin Ophthalmol. 2013;7:1503-1509.
Clinical Ophthalmology

\section{Publish your work in this journal}

Clinical Ophthalmology is an international, peer-reviewed journal covering all subspecialties within ophthalmology. Key topics include: Optometry; Visual science; Pharmacology and drug therapy in eye diseases; Basic Sciences; Primary and Secondary eye care; Patient Safety and Quality of Care Improvements. This journal is indexed on

\section{Dovepress}

PubMed Central and CAS, and is the official journal of The Society of Clinical Ophthalmology (SCO). The manuscript management system is completely online and includes a very quick and fair peer-review system, which is all easy to use. Visit http://www.dovepress.com/ testimonials.php to read real quotes from published authors. 